\title{
Filsafat Sosial Dalam Paradigma Al-qur'an: Dekonstruksi Teori Konflik Perspektif Barat
}

\author{
M. Fauzan Zenrif \\ Ketua LKQS STAIN Malang, Sedang menempuh Program Doktor di IAIN Sunan Ampel Surabaya
}

\section{Absract}

The objective of this stucty is to analyze the concepts of social philosophy in al-Qur'an, especially the theory of conflict. By making use a Thematically. Approach, and of a Historical and Socio-Anthropological interpretation and analysis, it finds some concepts of Islamic social philosophy which has differences in confronting with a modern (Western) concept of conflict. It also finds the impact of these concepts in Islamic tradition for social transformation by the Muhammad saw era.

Perbincangan sosiologi dalam dunia Islam pada dasamya bukan sesuatu yang baru, sebab ilmu ini telah menjadi perbincangan para pakar kemasyarakatan Muslim dari dulu hingga saat ini. Dalam filsafat sosial Ibn Khaldun, misalnya, sebuah negara dipandang tidak berbeda dengan makhluk hidup. Ia mempunyai unsur yang sama, lahir, tumbuh berkembang dan mati. Juga menarik diperhatikan bahwa Ibn Khaldun memandang perkembangan sebuah negara dapat berbeda berdasarkan waktu dan tempat geografis. Akan tetapi, secara umum, perjalanan sebuah negara membutuhkan tiga generasi untuk mencapai titik kesempurnaannya. ${ }^{1}$ 
Sementara itu, Ali Syari' ati memandang bahwa telah terjadi perubahan dalam masyarakat Syi'ah, yaitu dari masyarakat Syi'ah Ali yang indeterministik ke Masyarakat Syi'ah Safawiyah yang deterministik. Masyarakat Syi'ah Ali, menurut Syari'ati, adalah masyarakat yang dinamis dan revolusioner, ${ }^{2}$ sedangkan masyarakat Syi'ah Safawi adalah masyarakat Syi'ah yang pasif dan stagnan. Perubahan masyarakat Syi' ah dari dinamis menjadi pasif ini disebabkan adanya pola orientasi politik Dinasti Safawiyah sebelum kepemimpinan Pahlevi yang telah menjadikan Syi'ah sebagai agama negara. Pola orientasi ini pada akhirnya berdampak pada kekuasaan kaum ulama (ruhaniyyun) yang sangat kuat dan mempengaruhi perilaku masyarakat Syi'ah. ${ }^{3}$

Berangkat dari sini, Ali Syari'ati membagi tipologi masyarakat Syi' ah pada Syi'ah Asli (Pure Syi'ism) dan Syi'ah Palsu (Replication Syi 'ism). Abu Dzar alGhifari dan Imam Husein bin Ali bin Abi Thalib, menurut Syari'ati, merupakan simbol perubahan dinamis masyarakat $P$ ure Syi 'ism yang mengambil posisi sebagai oposan dari para penguasa yang lalim dan diktator. ${ }^{4}$ Sedangkan komunitas ulama yang mendukung kepemimpinan Safawi merupakan tipologi komunitas Syi'ah yang berfungsi sebagai "penjinak" masyarakat tertindas."

Melihat realitas masyarakat Syi'ah pada masanya, Syari'ati menyimpulkan bahwa sentral penggerak masyarakat bukan berada pada tangan atau kekuasaan ulama(ruhaniyyun)melainkan para cendekia dan intelektual Syi' ah yang mempunyai kepedulian terhadap ketidadilan sosial yang mampu merubah dan menggerakkan masyarat menuju Syi'ah ideal yang sebenamya dan menghasilkan kebudyaan baru. ${ }^{6}$ Untuk mencapai gerakan yang dinamis, masyarakat Syi'ah harus melakukan dua revolusi, yaitu revolusi politik dan revolusi sosial. Revolusi politik berfungsi untuk menghilangkan dominasi Barat terhadap negara-negara Dunia Ketiga dan sekaligus merevitalisasi kebudayaan dan identitas negara Dunia Ketiga. Sedangkan revolusi sosial berfungsi untuk menghilangkan seluruh bentuk eksploitasi dan kemiskinan guna menciptakan masyarakat yang adil, dinamis dan tanpa kelas sosial (menghilangkan rasisme). ${ }^{?}$

Kedua pandangan tokoh besar tersebut menggambarkan bahwa sejak dulu hingga sekarang sosiologi merupakan salah satu perbincangan ilmiah kaum intelektual muslim. Menarik diperhatikan, bahwa Ibn Khaldun mendasari filsafat realitas sosialnya, salah satunya, dengan berlandaskan pada informasi al-Qur'an. dengan kata lain, bahwa al-Qur'an bagi Ibn Khaldun bukan hanya menjadi sumber 
informasi spritual,melainkan juga menjadi sumber infromasi ilmu pengetahuan. Berangkat dari kenyataan bahwa al-Qur'an dapat pula dijadikan sebagai informasi penegetahuan ini, penelitian yang saya lakukan ini juga berlandaskan pada al-Qur'an sebagai pusat informasi pengetahuan filsafat sosial "islami" dengan menfokuskan pada permasalahan-permasalahan: Bagaimanakah konsep konflik dalamperspektif al-Qur'an? Adakah pemaknaan filosofis al-Qur'an tentang konflik berbeda dengan teori konflik Barat?

\section{Kajian Teoritik}

Teori konflik pada mulanya merupakan sebuah teori yang beranggapan bahwa seluruh kehidupan sosio budaya ditentukan oleh pertentangan antara dua kelas sosial yang terlibat dalam proses produksi, yaitu kaum industriwan yang mengontrol alat-alat produksi, dan kaum proletariat. ${ }^{8}$ Dalam pandangan ini, konflik memberikan kontribusi terhadap pemersatu suatu komunitas. Sekalipun logika ini tidak sepenuhnya dapat diterima karena mempunyai banyak kelemahan, akan tetapi logika ini dapat mengurai permasalahan evolusi dan progres sosial.

Pada sisi lain, konflik dianggap sebagai perselisihan mengenai nilai-nilai atau tuntutan-tuntutan berkenaan dengan status, kuasa, dan sumber-sumber kekayaan yang persediaannya tidak mencukupi. Dalarn hal ini, pihak-pihak yang sedant berselisih tidak hanya bermaksud menguasai barang-barang, melainkan juga memojokkan, merugikan, atau menghancurkan lawan mereka. Sekalipun memojokkan, merugikan, atau menghancurkan lawannya, konflik disebut sebagai unsur interaksi yang penting, dan sama sekali tidak boleh dikatakan tidak baik atau memecah belah, apalagi merusak. Justeru konflik memberikan banyak kontribusi terhadap kelestarian kelompok dan mempererat hubungan antara anggotanya. ${ }^{9}$

Di samping itu, teori konflik membedakan dengan jelas antara perasaanperasaan subyektif, seperti amarah, kebencian, antipati, keinginan akan balas dendam, dengan relasi-relasi pertentangan yang obyektif dan struktural. Dalam hal ini, teori konflik dipertentangan dengan teori fungsional (integrasi atau sistem). Berikut ini adalah perbedaan antara dua teori dalam sosiologi tersebut: 


\begin{tabular}{c|l|l|l|}
\hline No & Realitas Sosial & \multicolumn{1}{|c|}{ Fungsionalisme } & \multicolumn{1}{c|}{ Konflik (Koresi) } \\
\hline 1 & Struktur Sosial & $\begin{array}{l}\text { Struktur sosial terdiri dari } \\
\text { unsur-unsur yang relatif } \\
\text { kuat dan mantap }\end{array}$ & $\begin{array}{l}\text { Struktur sosial mengalami } \\
\text { proses perubahan yang } \\
\text { terdapat dimana-mana }\end{array}$ \\
\hline 2 & $\begin{array}{l}\text { Unsur dalam } \\
\text { struktur sosial }\end{array}$ & $\begin{array}{l}\text { Berinteraksi satu sama lain } \\
\text { dengan baik }\end{array}$ & $\begin{array}{l}\text { Memperlihatkan } \\
\text { perbantahan dan konflik }\end{array}$ \\
\hline 3 & $\begin{array}{l}\text { Fungsi setiap } \\
\text { unsur }\end{array}$ & $\begin{array}{l}\text { Menyumbangkan } \\
\text { ketahanan dan kelestarian } \\
\text { sistem }\end{array}$ & $\begin{array}{l}\text { Menyumbangkan pada } \\
\text { disintegrasi dan perubahan }\end{array}$ \\
\hline 4 & $\begin{array}{l}\text { Dasar struktur } \\
\text { sosial }\end{array}$ & $\begin{array}{l}\text { Kesesuaian paham antara } \\
\text { anggota tentang nilai-nilai } \\
\text { tertentu }\end{array}$ & $\begin{array}{l}\text { Keterpaksaan mayoritas atas } \\
\text { ketentuan minoritas }\end{array}$ \\
\hline
\end{tabular}

Bagan tersebut menggambarkan bahwa fungsionalisme memandang realitas atau unit-unitnya sebagai sistem atau jaringan relasi-relasi integratif, bagiannya berintegrasi dan saling bergantungan. Dengan demikian, tampak dengan jelas bahwa fungsionalisme beralaskan filsafat realisme. Sementara itu, teori konflik melihat realitas tidak dari sistem sosial, melainkan memandang sebagai himpunan dari individu-individu yang digabungkan oleh pihak-pihak berwenang. Dari sini dipahami bahwa teori konflik menganalisis realitas sosial dalam dua kategori, yaitu orang yang berkuasa dan mereka yang dikuasai. Akhimya, konflik dipahami sebagai suasana terbaginya kedudukan sosial yang mengakibatkan kepentingan-kepentingan yang antagonistis di antar mereka yang bersangkutan. Kelompok-kelompok yang antagonistis tersebut dapat dibagi pada dua kategori, yaitu kelompok potensial dan kelompok aktual, ${ }^{10}$ yang terjadi antara individu-individu, kumpulan-kumpulan (collectivities), antar individu dengan kumpulan. ${ }^{11}$

\section{Metode Penelitian}

Saya melihat bahwa al-Qur'an memberikan gambaran dengan jelas bagaimana kondisi-kondisi sosial dipandang dari teori konflik tersebut. Dalam makalah ini, saya akan mendeskripsikan konflik sosial dalam paradigma al-Qur'an dengan menggunakan pendekatan maudlu ' $i$ (tematik), yaitu metode yang pertama kali dikenalkan Muhammad Syaltut pada awal tahun 1960.12 Pendekatan ini 
kemudian dikembangkan al-Syathibi dengan lebih jelas, yang kemudian oleh beberapa kalangan dianggap sebagai founding father-nya ide tamaktik ketika ia mengatakan bahwa masalah-masalah yang terdapat dalam satu surat al-Qur'an mempunyai keterkaitan antara satu dengan lainnya. ${ }^{13}$

Metode tematik selanjutnya dikenal dalam dua bentuk pendekatan. Pertama, dilakukan dengan jalan menghubung-hubungkan permasalahan (topik persoalan) yang beraneka ragam dalam satu surat. Kedua, dilakukan dengan jalan menghubunghubungkan satu topik persoalan yang terdapat dalam beberapa surat. ${ }^{14}$ Studi yang akan saya di sini menggunakan pendekatan yang terakhir disebutkan. Untuk itu, operasional studinya dikerjakan dengan menggunakan langkah-langkah: (1) Menetapkan pokok persoalan yang akan dikaji; (2) Melacak dan menghimpun ayatayat yang terkait. Pada kegiatan ini saya menggunakan kitab al-Mu'jam alMufahras li al-Fadh al-Qur'an al-Karim karya Muhammad Fuad 'Abd al-Baqi yang diterbitkan Dar al-Fikr di Bairut pada tahun 1987. Disamping itu, komputerisasi al-Qur'an yang berkembang sejak akhir abad XX juga saya pergunakan untuk melacak ayat-ayat yang berhubungan dengan persoalan yang sedang dikaji; (3) Menyusun ayat-ayat yang telah ditemukan secara runtut berdasarkan kronologi turunnya. Dalam kegiatan ini saya menggunakan kitab-kitab Ulum al-Qur'an, khususnya yang berhubungan dengan topik Asbab al-Nuzul dan al-Maky wa alMadany;15 (4) Menganalisis kata yang sedang diteliti secara tekstual dan konstekstual. Dalam kegiatan ini peneliti menggunakan metode analisis semantik ${ }^{16}$ dan historis-sosiologis. Di samping dua model analisis ini peneliti juga menggunakan analisis Ushuliyah: ${ }^{17}$ (5) Menganalisis hubungan korelasional ayat yang sedang diteliti dengan ayat sebelum dan sesudahnya dalam masing-masing surah. Kegiatan ini akan banyak menggunakan ilmu munasabah; ${ }^{18}$ dan (6) Menyusun tema bahasan dalam kerangka yang utuh dan sistematis guna memperoleh paradigma dan konsep yang komprehensif.

\section{Teori Konflik dalam al-Qur'an}

Dari hasilpenelitian saya, ditemukan bahwa al-Qur'an menggambarkan konflik sosial dalam dua bentuk, yaitu dalam bentuk potensial dan aktual. Konflik dalam bentuk potensial disebutkan al-Qur'an dengan menggunakan kata "عد و" 
(permusuhan), sedangkan konflik aktual digambarkan dengan menggunakan kata " (20rselisihan/pertengkaran) dan " خصر" "

\section{Konflik Potensial}

Kata " عد و" dan beberapa kata bentukannya menggambarkan potensi konflik. Dari hasil analisis terhadap beberapa ayat al-Qur'an, ditemukan bahwa secara umum potensi konflik dapat dibagi pada, yang saya sebut dengan, potensi konflik universal, dimana potensi ini terbagi pada potensi konflik intrapersonal dan interpersonal. Yang saya maksudkan dengan potensi konflik universal ialah potensi berselisih yang dimiliki setiap individu dalam interkasi sosial. ${ }^{19}$ Potensi ini dimiliki oleh setiap kita, sekalipun barangkali kita tidak pernah kenal dengan orang yang baru pertama kali bertemu dalam sebuah perjamuan malam misalnya, akan tetapi karena satu hal yang tidak berkenan pada kita, baik berupa perilaku, tutur kata, maupun wama dan mode busana yang dipakainya, kita dapat saja mempunyai kesan tidak senang padanya. Jelasnya, potensi konflik universal tidak membutuhkan adanya interaksi atau kontak sosial sebelumnya, sebab potensi ini melekat dalam diri setiap individu. Potensi konflik universal ini dapat berbentuk potensi konflik intrapersonal dan interpersonal.

Konflik intrapersonal adalah potensi konflik yang muncul dalam "diri" setiap pribadi, yakni potensi perselisihan antara dorongan-dorongan kebaikan ${ }^{20}$ dan keburukan. ${ }^{21}$ Dorongan untuk melawan atau menyatakan permusuhan terhadap kebaikan selalu menunjukkan adanya dorongan pada kejahatan dan keburukan. Sebaliknya, adanya kesadaran melawan dorongan kejahatan menunjukkan pada kuatnya dorongan kebaikan, ${ }^{22}$ dalam "diri" setiap individu. Kondisi konflik intrapersona ini sering dialami ketika kita menghadapi pilihan untuk melakukan atau menolak mengerjakan sesuatu. Dalam kondisi seperti ini, kita dapat saja menyalahkan dan membenci, bahkan menyakiti dan membunuh, "diri" kita sendiri.

Potensi konflik interpersonal ialah potensi yang ada dalam "diri" setiap kita untuk memusuhi dan membenci orang lain. Potensi ini dapat berbentuk individuindividu ${ }^{23}$ antar-individu dalam keluarga ${ }^{24}$ antar-individu yang sudah dijalin dengan komitmen persahabatan ${ }^{25}$ antar etnis atau komunitas masyarakat yang diikat dengan komitmen, baik komitmen tersebut dalamkerangka kebangsaan atau kenegaraan ${ }^{26}$ 
maupun komitmen keagamaan. ${ }^{27}$ Potensi konflik yang didasarkan atas komitmen keagamaan, di samping disebabkan permasalahan politik dan ekonomi, banyak didorong oleh penilaian yang negatif, yang berakhir dengan pengejekan pada agama lain. ${ }^{23}$

Dilihat dari pandangan strukturalis, ada potensi konflik antara pimpinan, raja, presiden, rektor, atau direktur pada satu sisi, dan rakyat, mahasiswa, atau buruh pada lawan sisinya. ${ }^{20}$ Potensi "konflik struktural" ini merupakan akibat dari ketidakadilan, kedhaliman, dan bentuk lain dari penindasan kaum elit terhadap masyarakat alit (kecil) ${ }^{30}$ Dalam pandangan struktur agama, potensi konflik dapat terjadi antara nabi, kyai, pendeta, pastur, biksu atau missionaris (da'i), dengan umatnya pada sisi lain. ${ }^{31}$

Potensi konflik yang terakhir ini disebabkan ada sebagian masyarakat yang bersifat munafik dan menjadi demagog, dimana kebanyakan masyarakat dan pimpinan terpengaruh oleh keindahan bahasa atau rasionalisasi analitis para demagog ini. Sekalipun analisis para demagog tidak berdasarkan realitas yang sebenarnya, akan tetapi demagog tersebut mampu merasionalisasikan informasinya sehingga seakan-akan apa yang diinformasikannya benar-benar berangkat dari sebuah realitas. ${ }^{32}$ Tindakan yang berangkat dari hasil analisis para demagog telah mengakibatkan kaum elit mengambil kebijakan yang kurang tepat dan sebagian masyarakat memberikan penilaian terhadap pimpinan dengan salah disebabkan informasi demagog yang tidak benar itu. Realitas sosial seperti ini dapat terlihat dengan jelas dalam dinamika sosio-politik Indonesia belakangan ini.

\section{Konflik Aktual}

Konflik potensial yang disebutkan pada bagian sebelumnya, apabila diorganisir dan disertai dengan mobilitas sosial, maka ia akan menjadi konflik aktual, yakni realitas konflik sosial. Dalam hal ini al-Qur'an menggambarkan dengan " قتل" pada tingkat konflik yang paling rendah, dan kata" خم" " untuk tingkatan konflik yang tinggi.

Menurut informasi al-Qur'an, konflik sosial yang terendah ditunjukkan dalam berbagai model konflik; Pertama, dengan hadimya seorang demagog yang memberikan rasionalisasi yang menakjubkan tentang keberhasilan kehidupannya 
dan ditampakksn di depan orang banyak atas nama Tuhan, walaupun sesunggubnya yang berada di dalam jiwanya adalah kebalikan dari apa yang ada pada permukaan. Yang ada dalam hatinya jauh dari kenyataan yang ditampakkannya di depan orang banyak. Apabila dia berada di belakang orang banyak, dia justeru membuat kerusakan di atas bumi, apabila diingatkan atas perilakunya tersebut, dia menumjukkan kesombongan dan keangkuhannya ${ }^{33}$ Dalam realitas Indonesia, konflik seperti ini secara fenomenologis dapat dilihat dari cara analis politik yang telah mengakibatkan terjadi konflik sosial dan lebih jauh mengakibatkan nuntuhnya tata susila bangsa Indonesia.

Kedua, konflik sosial yang didahului oleh perdebatan (mujadalah), ${ }^{34}$ yaitu perdebatan antara logika yang benar dengan logika yang salah, kebaikan dengan kebunukan, dan antara keadilan dengan kebatilan. Konflik seperti ini sering terjadi antara mereka yang mengajak kepada kebenaran dan mereka yang mempertahankan tradisi yang salah. ${ }^{35}$ Konflik seperti ini saat sekarang dapat dilihat dalam perdebatan yang sering dimunculkan dalam berbagai mass media yang secara umum dapat dikategorikan kepada dua kelompok tadi.

Ketiga, konflik keluarga disebabkan penmasalahan kekeluargaan, seperti pengasuhan anak, pemilikan terhadap harta waris, kecemburuan terhadap pasangannya, dan segala bentuk konflik keluarga. ${ }^{36}$ Konflik seperti ini banyak terjadinya di negara-negara maju maupun berkembang yang fenomenanya dapat dilihat dari meningkatnya angka perceraian dan gugat cerai (bagi negara-negara Islam). ${ }^{37}$

Keempot, "perang dingin" antarumat beragama, yaitu konflik antarumat beragama, kelompok mukmin pada satu sisi dan kelompok kafir pada sisi lain. ${ }^{38}$ Konflik seperti ini ialah konflik yang terselubung dalam setiap perdebatan dan kajian keagamaan. Secara akademik, kita melihat konflik ini dalam berbagai literatur tentang kajian keagamaan, dimana masing-masing pengkaji menyatakan yang paling objektif dan akhimya membenarkan agamanya masing-masing.

Kelima, konflik antara orang yang melakukan perserikatan dan kerjasama dengan tidak menggunakan manajemen yang baik. ${ }^{39}$ Sistim kerjasama atau perserikatan ini dapat terjadi dalam skala personal, komunitas sosial yang diwakili oleh organisasi, institusional (antarlembaga), regional (antarpropinsi), nasional (antarnegara) maupun intemasional (antara negara-negara yang berkelompok dalam suatu badan atau organisasi). Setiap hubungan kerjasama atau perserikatan yang 
dilakukan dengan cara tidak profesional dan terbuka, merupakan bentuk dari konflik sosial yang apabila terakumulasi akan menjadi ledakan konflik yang membahayakan hubungan tersebut.

Keenam, konflik sosial diakibatkan perbedaan pandangan tentang kekayaan dan konservasi alam, perbedaan pandangan ini berakibat pada upaya untuk mempertahankan pandangan yang karena ketidaktahuannya mengakibatkan pada kesalahan, namun dengan kesombongannya kemudian berwujud dalam bentuk makar. ${ }^{* 0}$ Makar ini ditunjukkan dengan cara mengeksploitasi alam untuk menunjukkan kebenaran dan kemenangannya sehingga mengakibatkan kerusakan eko sistem dan makro kosmik. Pada dunia kita sekarang, kita melihat bagaimana Barat (negara-negara industri) telah menghabiskan seluruh kekayaan alamnya untuk dieksploitasi demi kepentingan industrialisasi, namun pada sisi lain Barat meminta agar negara-negara tertinggal di Timur melakukan konservasi alam demi keutuhan eko sistem dan makro kosmik. Konflik seperti ini sring tampak kepermukaan dalam bentuk "perang dingin" antara Barat (negara kaya) dan Timur (negara miskin).

Ketujuh, bentuk konflik sosial diakibatkan terjadinya pencurian, korupsi, manipulasi, pengurangan timbangan atau ukuran, dan beberapa bentuk pengambilan hak orang lain dengan tidak sah. ${ }^{41}$ Korupsi dan manipulasi yang terjadi di beberapa negara berkembang, khususnya Indonesia, telah mengakibatkan terjadinya konflik sosial, baik vertikal maupun horisontal. Terjadinya demonstrasi di berbagai daerah sebagai bentuk respon terhadap terjadinya korupsi dan manipulasi adalah salah satu indikasi yang menunjukkan terjadinya konflik bentuk ini.

Sementara itu, kata “قَّل "yang menunjukkan pada tingkatan konflik aktual yang tinggi dapat terjadi antarpersonal yang diakibatkan permasalahan keluarga. baik karena permasalahan perkawinan yang tidak disetujui maupun disebabkan masalah warisan, ${ }^{42}$ antar-etnis dan agama yang disebabkan fitnah. ${ }^{43}$ antamegara (pemerintahan), ${ }^{44}$ atau peperangan antaragama (perang suci). ${ }^{45}$ Bentuk-bentuk konflik ini hingga kini dapat kita amati dengan jelas dalam berbagai kehidupan sosial, sekalipun dengan motif dan dorongan yang berbeda dengan apa yang ada dalam setiap ayat secara tekstual.

Fenomena konflik sosial ini dapat dilihat dari terjadinya pembunuhan yang tidak disengaja atau melakukan sesuatu dengan tidak bermaksud untuk membunuh, akan tetapi secara tidak langsung mengakibatkan terjadinya pembunuhan, ${ }^{46}$ atau pembunuhan terhadap individu atau perusakan terhadap alam semesta, ${ }^{47}$ 
pembunuhan terhadap pimpinan (negara maupun agama), ${ }^{48}$ atau pembunuhan terhadap anak sendiri. ${ }^{49}$

\section{Kesimpulan dan Saran}

Sebagai kesimpulan dari penelitian ini, saya temukan suatu teori konflik yang berbeda dengan teori filsafat yang ditemukan para sosuiolog Barat, sekalipun sebagian konsep al-Qur'an mempunyai kesamaan dengan teori konflik Barat, akan tetapi perbedaan yang cukup signifikan ialah bahwa paradigma al-Qur'an tentang konflik lebih komprehensif, menyangkut inner dan outer dari pribadi manusia sehingga konsep-konsep yang diajukan al-Qur'an tanpak tidak memisahkan antara tendensi subyektif (psiokologis) maupun, menurut istilah teori konflik Barat, yang obyektif (sosiologis), bahkan al-Qur'an menyatukan sebuah konsep yang integratif antara konsep potensial dan aktual dalam satu sebab akibat yang fenomenanya dapat kita amati hingga saat ini.

Hal lain yang saya temukan, bahwa konflik dalam paradigma al-Qur`an tidak dianggap sebagai sesuatu yang positif, sebab sekecil dan sesempit apapun konflik yang terjadi, akan berpengaruh pada disharmoni sosial. Dengan demikian dapat dipahami bahwa sekalipun kita dapat mengamati fenomena konflik sosial, akan tetapi tujuan analisis tersebut adalah harmonisasi sosial. Oleh sebab itu, teori konflik di sini hanya dapat dipergunakan untuk menguraikan permasalahan sosial, bukan untuk dipraktikkan dalam kehidupan bermasyarakat.

Sebagai akhir dari penelitian ini, saya sadar bahwa masih ada beberapa hal yang belum saya lakukan secara serius dalam penelitian ini,misalnya penggunaan pendekatan hermenutik dalam menganalisis teks al-Qur'an. Oleh sebab itu. peneltiian setelah ini diharapkan mampu menggunakan pendekatan yang lebih konrehensif agar dapat mengekplorasi filsafat al-Qur'an tentang sosial secara lebih radikal.

Hal lain yang dapat dikembangkan dalam penelitian ini ialah bahwa al-Qur'an menunjukkan kepada kita beberapa hal yang mungkin hingga saat ini belum sempat diteliti oleh ulama-ulama atau cendekia Muslim.oleh sebab itu, doharapkan modelpeneltiian seperti ini dapat dikembangkan dalam semua studi al-Qur'an pada masing-masing jurusan umum di PTAI, setidaknya di Universitas Islam Indonesia Sudan ini. Wallahu a 'lam. 
'Abd al-Rahman Ibn Khaldun, Mugaddimah (Baint: al-Mathba'ah al-Adabiyah, 1886), 148

2 Afif Muhammad, Ummah dan Imamah (Jakarta:Pustaka Hidayah, 1989), 15.

3 John L. Esposito, Identitas Islam pada Perubahan SosialPolitik (Jakarta: Bulan Bintang, 1986), 159.

4 Saya berasumsi bahwa pandangan ini mempunyai kesamaan dengan Jamal Abd al-Nashr yang mencoba menghilangkan ketidaksamaan kesempatan bagi masyarakat untukmemperoleh harta benda dan mengakibatkan ketidakadilan. Lihat misalnya John. J. Donohue dan John L.Esposito, Islam dan Pembaharuan: Ennsiklopedi Masalah-masalah, terjemahan Machnun Hudein (Jakarta: Rajawali, 1989), 230.

5 John L. Esposito, "identitas", op. cit., 78.

6 ibid.

7 Azyumardi Azra, Pergolakan Pemkiran Islam dari Fundamentalisme, Modernisme hingga Post-Modernisme (Jakarta: Paramadina, 1996), 71.

8 Teori ini dikembangkan kalangan Marxian, terutama para pencetusnya Karl Marx (1818-1883) maupun oleh koleganya Friedrich Engels (1820-1895). Teoriteori kelompok ini, baik teori tentang sejarah, sosiologi maupun ekonominya, banyak dipengaruhi oleh teori the Origin of Species-nya Charles Darwin yang diterbitkan pada 1859. Analisis terhadap pandangan kelompok ini baca Scott Gordon, The History and Philosophy of Social Sciences (London and New York: Routledge, 1991), khususnya 328-38; juga KJ. Veeger, Realiras Sosial: Refleksi Filsafata Sosial atas Hubungan Individu-Masyarakat dalam (akrawala Sejarah Sosiologi (Jakarta: PT. Gramedia Pustaka Utama, 1993), 210-20.

9 Ibid., 211-12.

10 Ibid., 214-19.

11 Ibid., 211

12 Lihat Quraish Shihab, Membumikan al-Qur 'an: Fungsi Wahyu dalan Kehichupan Masyarakur (Bandung: Mizan, 1996), 73.

13 Baca Abu Ishaq al-Syathibiy, al-Muwafagat di (Ishul al-Syari'ah, Juz III (Bairut: Dar al-Kutub al-Ilmiah, t th ), h. 309.

14 'Abd al-Hayy al-Farmawi, Metode Tafsir Maudlu'i: Suatu Penganlar, diterjemahkan Suryani A. Jumrah (Jakarta: Rajawali Press, 1994), 35-6.

is Asbab al-Nuzul adalah suatu peristiwa yang menjadi sebab turun satu atau beberapa ayat, memberi jawaban terhadap sebab itu, atau menerangkan hukumnya pada masa terjadinya sebab tersebut. Sedangkan al-Makky dan alMadani adalah suatu pengetahuan yang dengannya diketahui kronologi turunnya ayat. Dengan ilmu ini pula maksud ayat dapat dijelaskan dengan baik. Lihat Subhi al-Shalih, Mabahils fi 'Ulum al-Qur'an (Bairut: Dar al-'Ilm al-Malayin, 1977), 132; Muhammad 'Abd al-Adhim al-Zarqani, Manahil al-'Irfan fi 'Ulum al-Qur 'an, Vol. I (Bairut: Dar al-Fikr, 1988), 99.

16 Dimaksud dengan analisis semantik disini, mengikuti pendapat Toshihiko Izutsu, adalah studi analitik terhadap term-term kunci sebuah bahasa dengan satu pandangan yang tujuan akhimya untuk mencapai suatu konsep dasar weltanschaunng atau world view dari penduduk yang menggunakan bahasa 
tersebut sebagai alat untuk membuat konsep dan memberikan interpretasi dunia yang ada di sekelilingnya. Lihat Toshihiko Izutsu, God and Man in the Koran (Tokyo: Keio University Press, 1964), 10. Untuk itu, analisis semantik sesungguhnya merupakan satu cara dari weltanschauung-slehre, satu studi terhadap natur, struktur dan world view suatu bangsa.

17 Analisis Ushuliyah adalah analisis terhadap teks dengan menggunakan kaidahkaidah ilmu ushul fiqh, seperti analisis lafal wudhuh dan thafa', konsep bayyan lofsir, amr, nahy, dan sebagainya. Dalam hal ini ada beberapa kitab yang cukup representatif dipengunakan seperti Abu Ishaq al-Syathibiy, op.cit; Muhammad Wafa, Dilalat al-Awamir wa al-Nowahiy fi al-Kitab wa al-Sunnah (Mesir: Dar al-Iththiba'ah al-Muhammadiyah, 1984); Muhammad Khudlariy Bik, Ushul alFigh (Baint: Dar al-Fikr, 1981); al-Amidiy, Al-Ihkam fi Ushul al-Ahkam (Medan: Maktabah: Muhammad Ali wa Auladih, 1968).

Ilmu Munasabah adalah ilmu yang dipergunakan untuk menemukan korelasi antar ayat atau surat dalam al-Qur'an. Baca Zahir 'Awad al-Alma'iy, Dirasah fi al-Tafsir al-Manudlu 'iy (Cet I; Riyadl: t.p., 1985), 77.

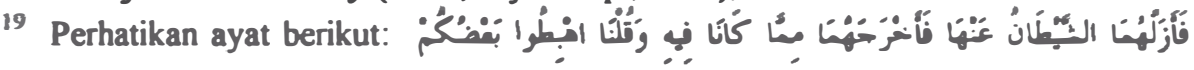

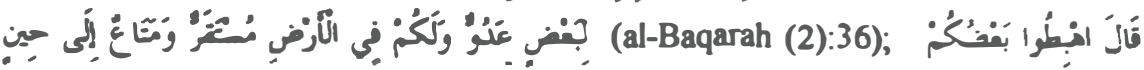

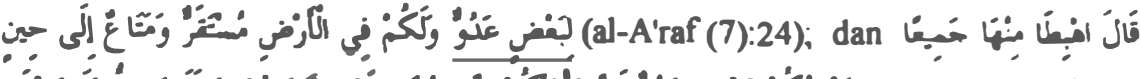

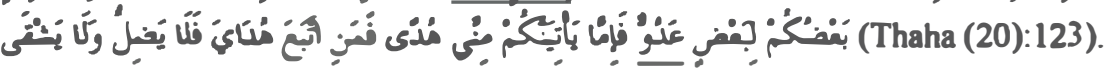

20 Hal ini digambarkan sebagai sebuah potensi "ketuhanan"dan "kemalaikatan" yang muncul dalam setiappribadi manusia mukmin. Potensi ini ditunjukkan oleh

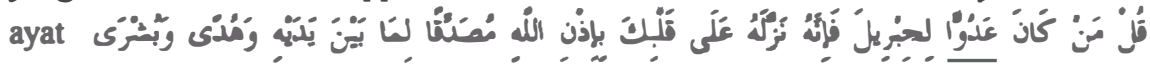

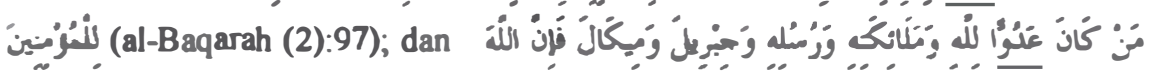

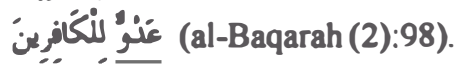

21 Hal ini digambarkan sebagai potensi "kesyetanan". Potensi ini ditunjukkan oleh

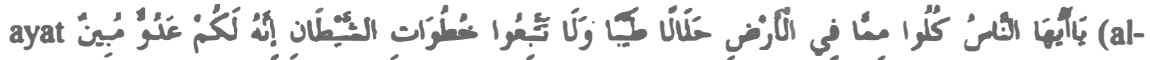

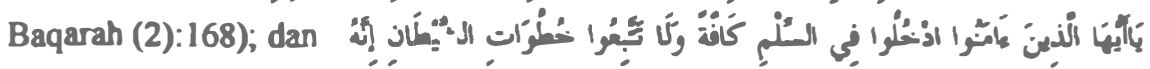

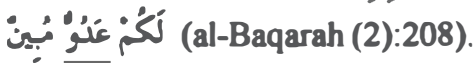

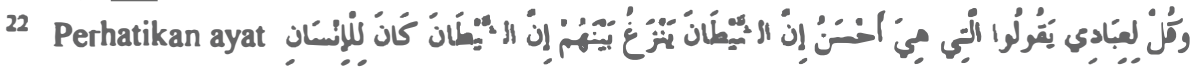

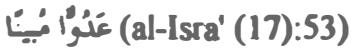

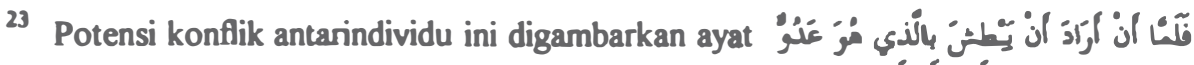

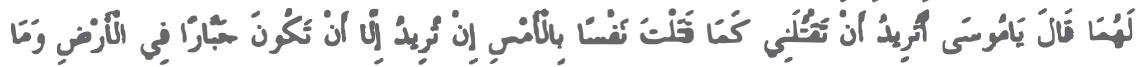

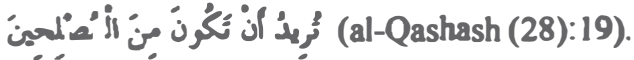

24 Keluarga yang dimakeudkan, baik bentukan kelurga yang didasarkan atas pertalian keturunan, seperti yang ditunjukkan ayat (al-Taghabun (64): 14), maupun keluarga yang didasarkan atas pertalian adopsi, seperti yang 


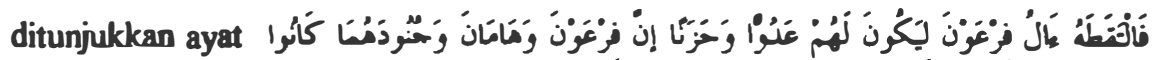

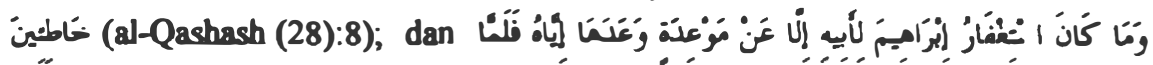

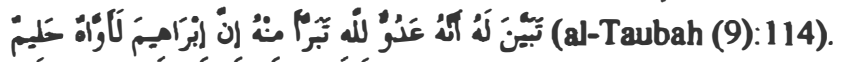

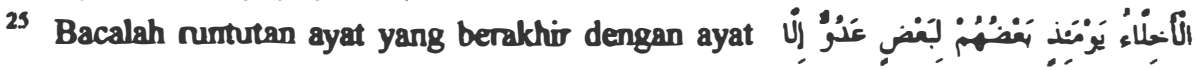

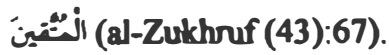

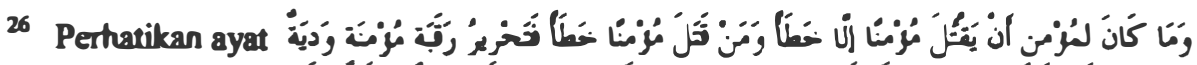

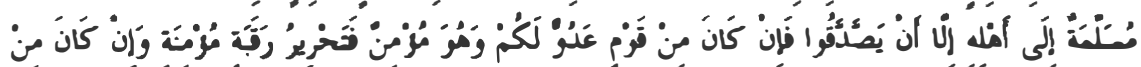

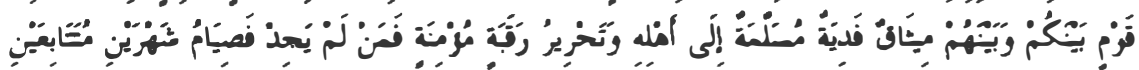

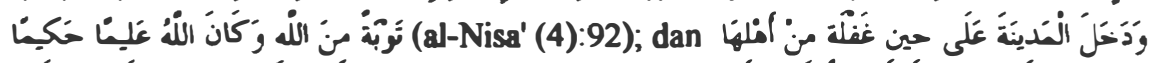

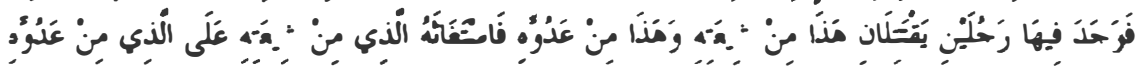

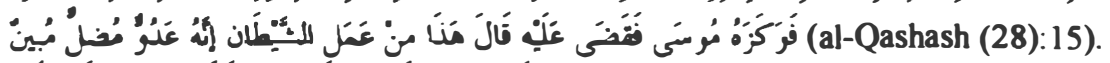

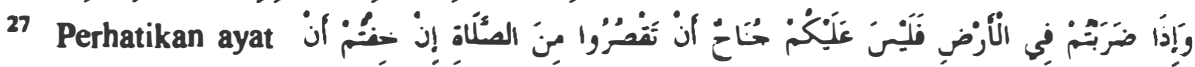

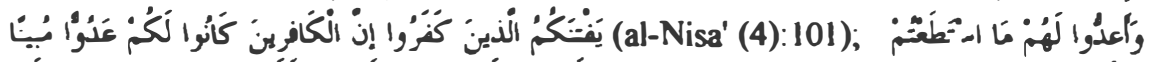

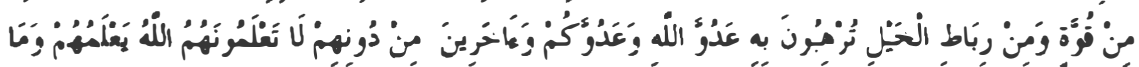

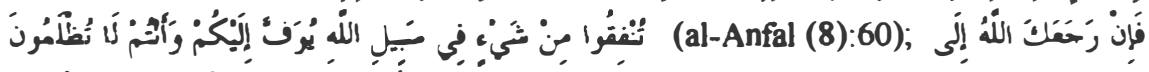

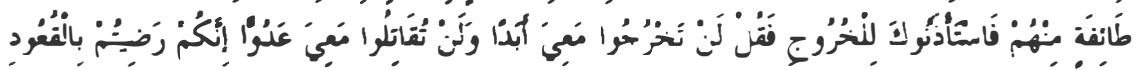

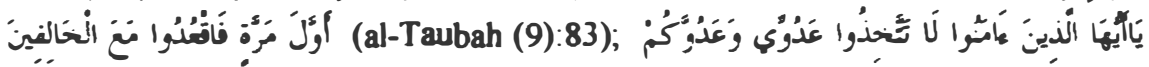

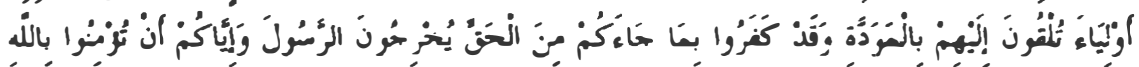

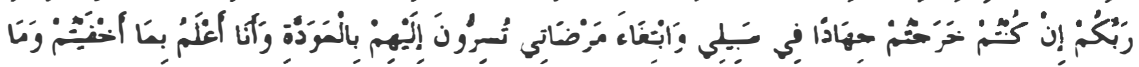

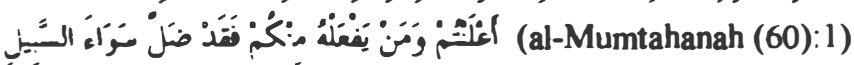

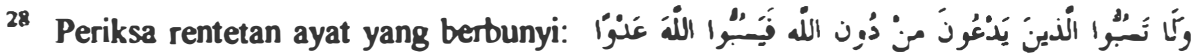

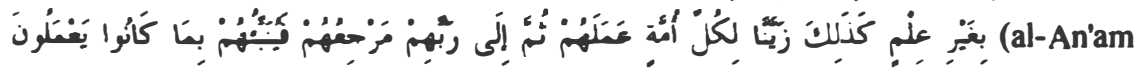
(6): 108).

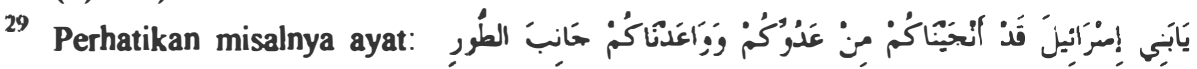

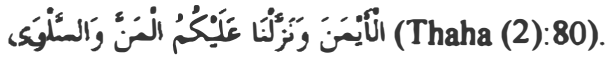

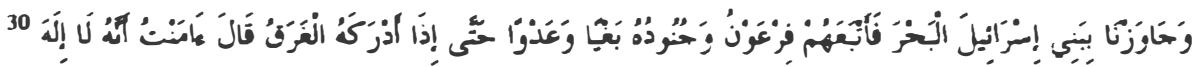

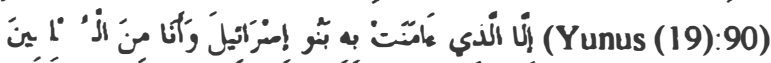

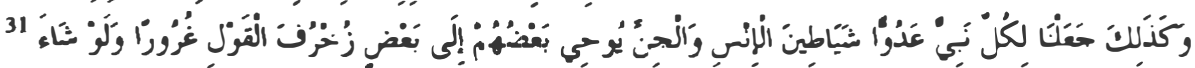

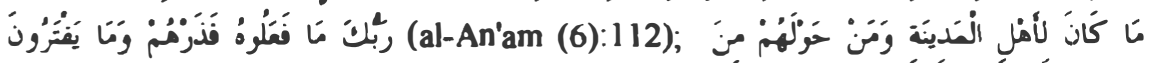

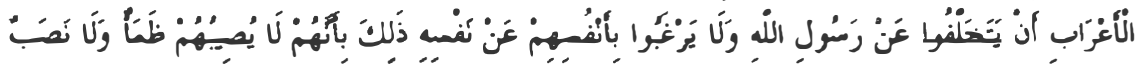

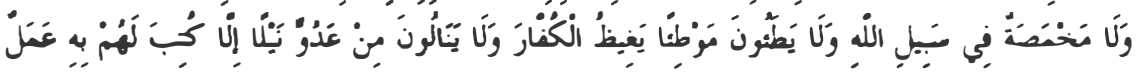

Ulul Albab, Vol. 4 No. 2, 2002 


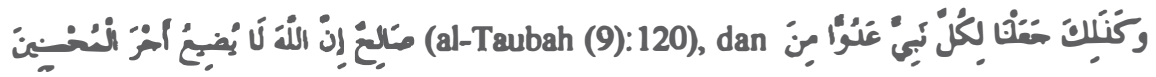

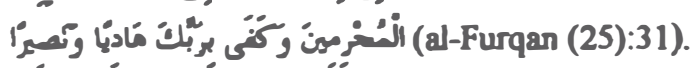

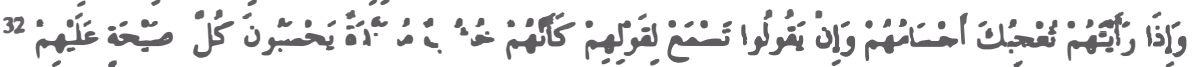

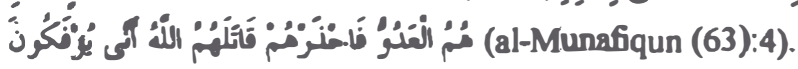

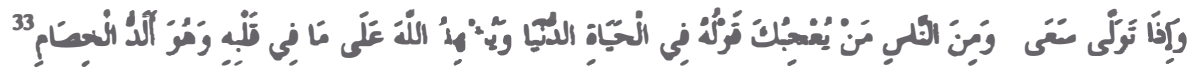

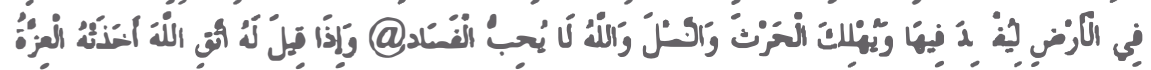

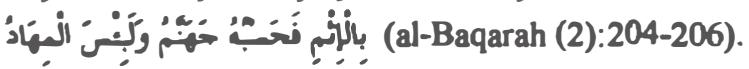

34 Mujadalah (debat) dan beberapakata jadiannya disebutkan al-Qur'an sebanyak 29 kali,dalam surat al-Baqarah (2):197), al-Nisa': 107 dan 109 (2 kali), alAn'am:25 dan 121, al-A'raf: 71, al-Anfal:6, Hud:32 (2 kali) dan 74, al-Ra'd:13), al-Nah:111 dan 125, al-Kahfi:54 dan 56, al-Haij:3, 8 dan 68, al-Ankabut:46, Luqman:20, al-Mukmin:4, 5, 35, 56, dan 69, al-Syu'ara':35, al-Zukhruf:58, dan al-Mujadilah:1.

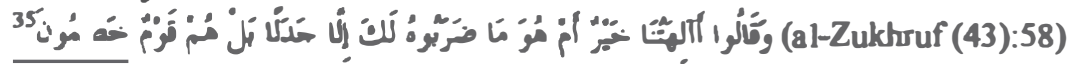

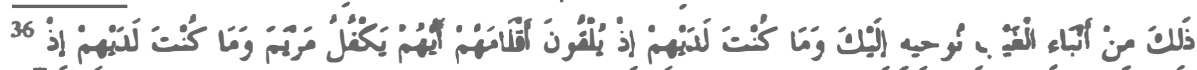

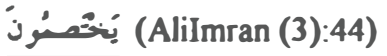

37 Di Indonesia dapat dilihat dalam data-data di Pengadilan Agama yang menunjukkan adanya kecendenungan kenaikan angka perceraian dalam setiap bulan, sedangkan di Pengadilan Negeri kita melihat meningkatnya perebutan hak milik dalam keluarga.

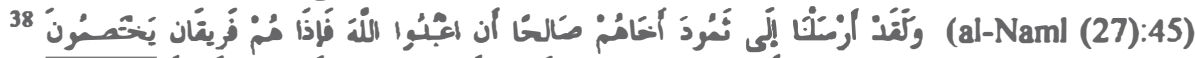

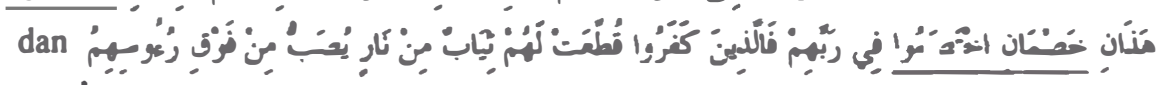
الْحِيمَ (al-Haji (22):19). sekalipun ayat tersebut masing-masing menggambarkan kondisi sosial yang terjadi masa Nabi Shalih dan Nabi Muhammad saw, akan tetapi kenyataan realitas sosial dapat memperlihatkan hal yang sama, yaitu terjadi konflik antara mereka yang mengajak pada jalan kebenaran dengan mereka yang mencoba untuk mempertahankan tradisi yang tidak benar.

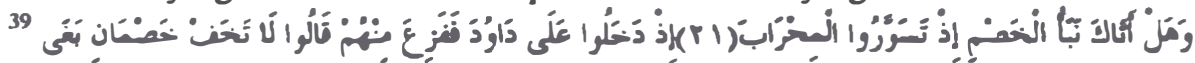

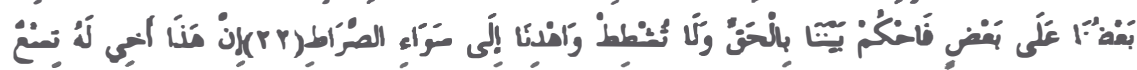

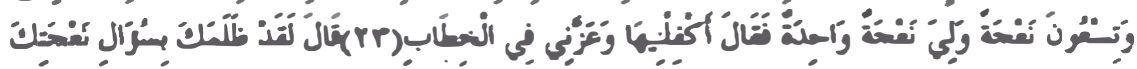

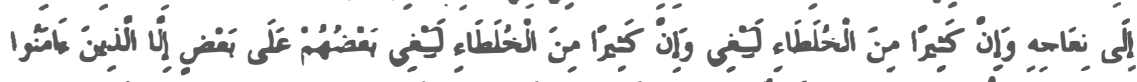

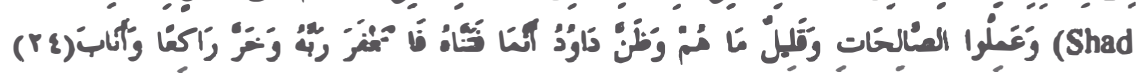
(38):21-24). Ayat ini secara lugas menceritakan terjadinya konflik diakibatkan sistim manajemen yang tidak baik dalam melakukan perserikatan.

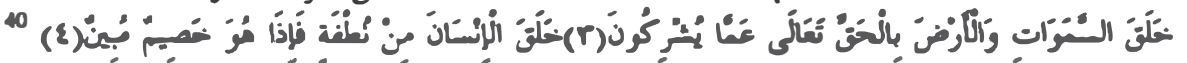

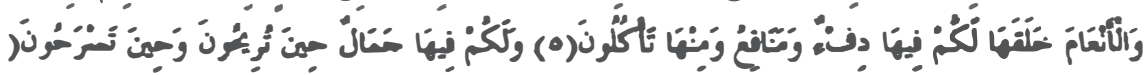

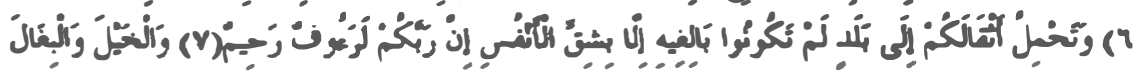




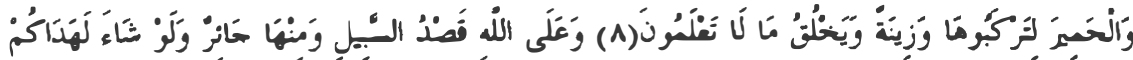

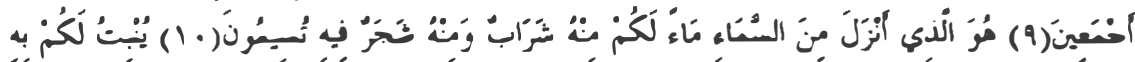

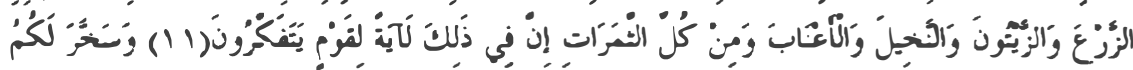

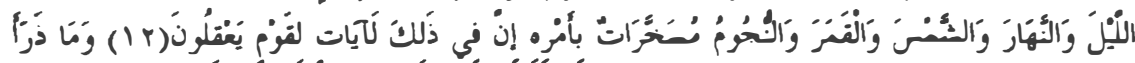

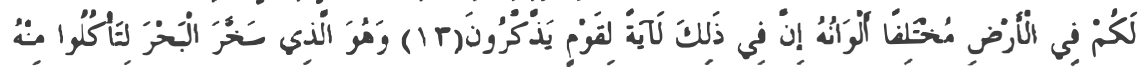

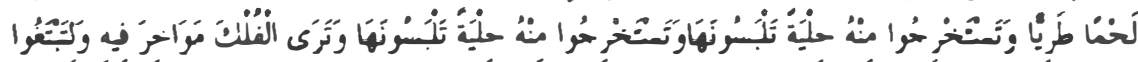

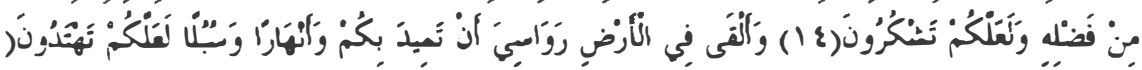

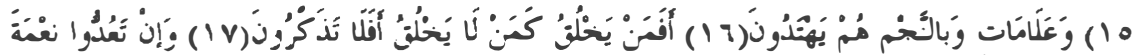

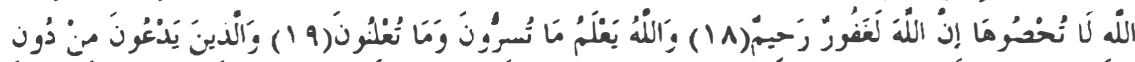

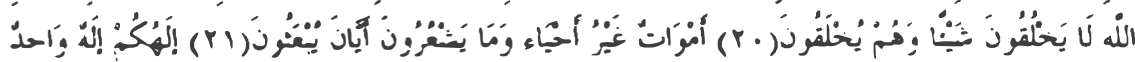

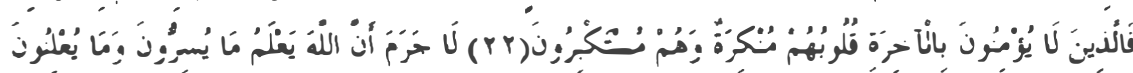

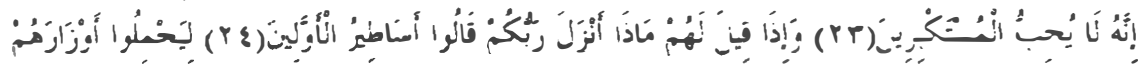

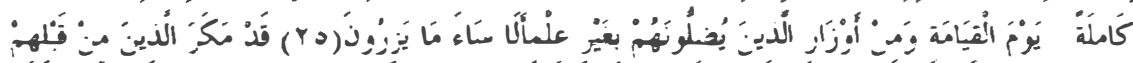

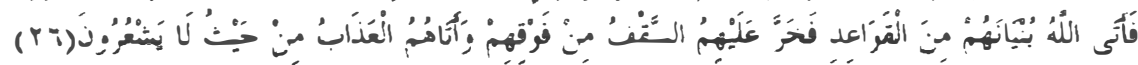
(al-Nahl (16):3-26)

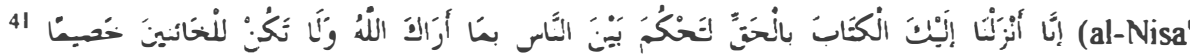
(4): 105), sekalipun ayat ini menggambarkan kondisi ketika mas Rasulullah saw, akan tetapi kandungan ayat ini juga menggambarkan telah terjadi konflik diakibatkan pencurian

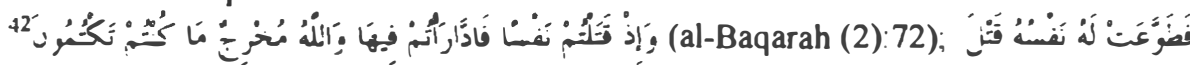
(al-Maidah (5):30)

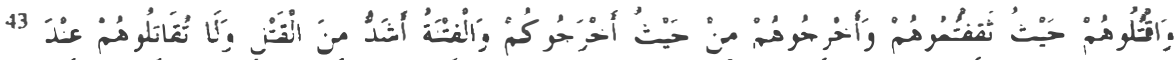

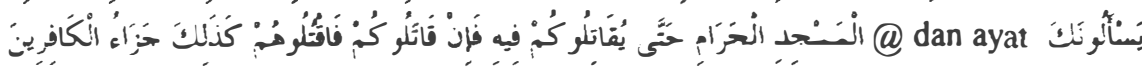

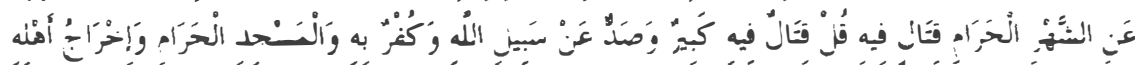

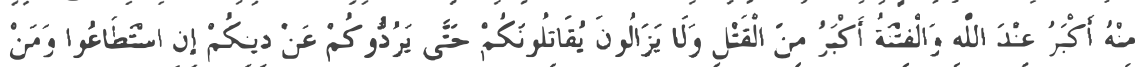

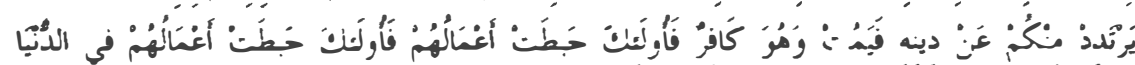

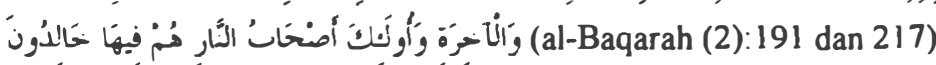

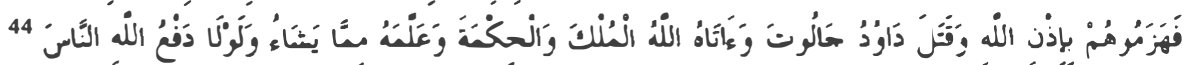

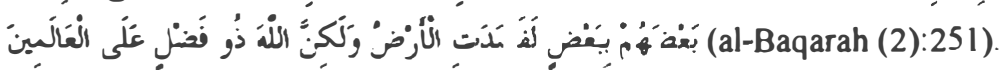

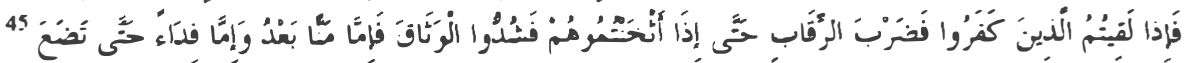

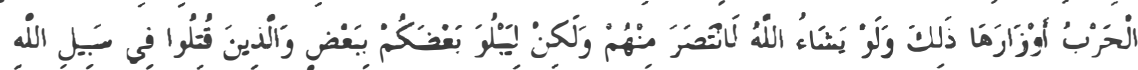

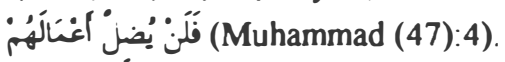




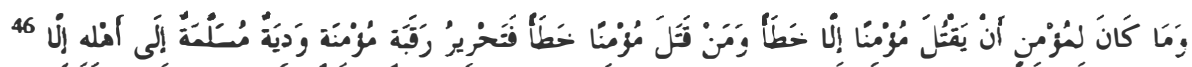

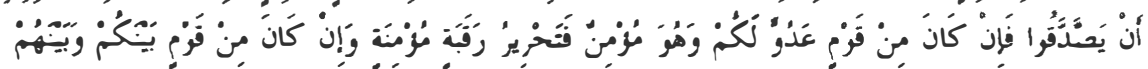

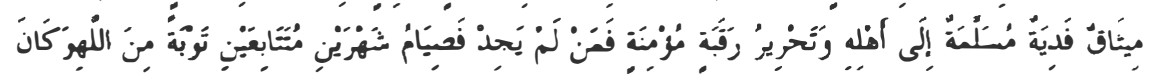
الله علينا خَكيما (al-Nisa' (4):92).

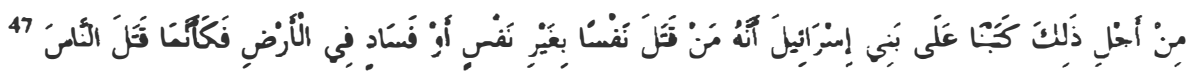

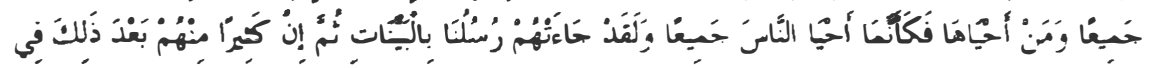

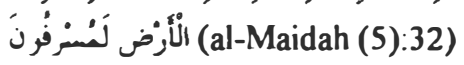

48 Al-Qur'an menggambarkan kebiasaan masyarakat yang membunuh para nabi,

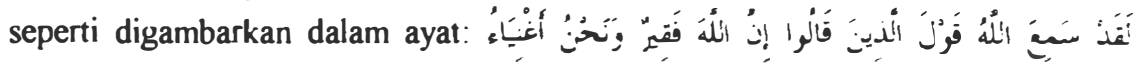

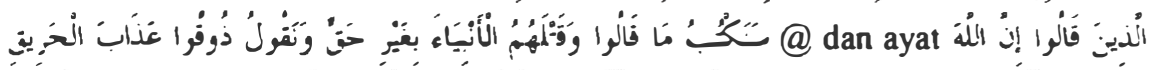

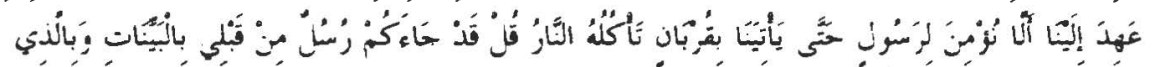

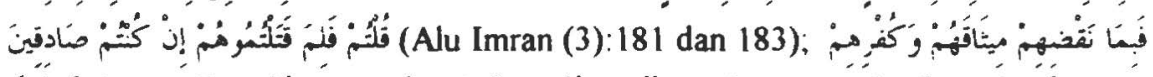

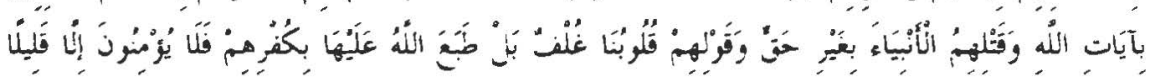
(al-Nisa' (4):155)

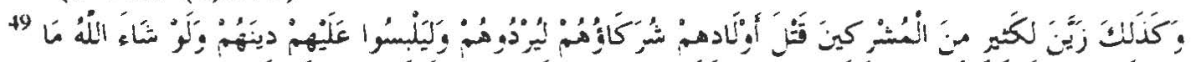

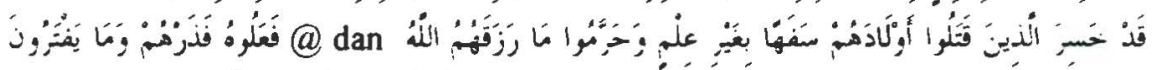

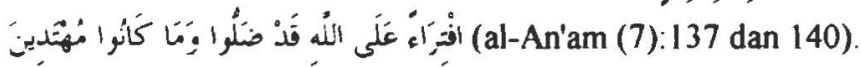




\section{Bibliography}

Abdulkader, Deina (1996) Social Justice in Islam. London: Intemational Institute of Islamic Thought.

al-Alma'iy, Zahir 'Awad (1985) Dirasah fi al-Tafsir al-Maudlu'iy. Cet I; Riyadl: t.p.

al-Amidiy (1968) Al-Ihkam fi Ushul al-Ahkam. Medan: Maktabah: Muhammad Ali wa Auladih.

Azra, Azyu Mardi (1996) Pergolakan Pemkiran Islam dari Fundamentalisme, Modernisme hingga Post-Modernisme. Jakarta: Paramadina.

Bik, Muhammad Khudlariy (1981) Ushul al-Figh. Bairut: Dar al-Fikr.

Donohue, John. J. dan John L.Esposito (1989) Islam dan Pembaharuan: Ennsiklopedi Masalah-masalah, terjemahan Machnun Husein. Jakarta: Rajawali.

Enan, Muhammad 'Abdullah (1953) Ibn Khadun: Hayatuh wa Turatsuh al-Fikr. Kairo: t.p.

Esposito, John L. (1992) Islam dan Politik, terjemahan. Bandung: Mizan.

(1986) Identitas Islam pada Perubahan Sosial Politik. Jakarta: Bulan Bintang.

al-Famawi, 'Abd al-Hayy (1994) Metode Tafsir Maudlu'i: Suatu Pengantar. Terjemahan Suryani A. Jumrah. Jakarta: Rajawali Press.

Gordon, Scott (1991) The History and Philosophy of Social Sciences. London and New York: Routledge.

Hasan, Riaz (1985) Islam dari Konservatisme sampai Fundamentalisme. Jakarta: Rajawali.

Ibn Khaldun, 'Abd al-Rahman (1886) Muqaddimah. Bairut: al-Mathba'ah alAdabiyah.

(1951) al-Ta'rif bi Ibn Khaldun wa Rihalatuh Gharban wa Syargan, disunting Muhammad Ibn Tawit al-Tanji. Kairo: Lajnah al-Ta'lif wa Tarjamah wa al-Nasyar.

Izutsu, Toshihiko (1964) God and Man in the Koran. Tokyo: Keio University Press, 
Leonard Binder (ed.) (1976) The Study of the Middle East: Research and Scholarship in the Humanities and the Social Sciences. New York: John Wiley \& Sons.

Mortimer, Edward (1984) Islam dan Kekuasaan, terjemahan Enna Hadi dan Rahmani Astuti. Bandung: Mizan.

Muhammad, Afif (1989) Ummah dan Imamah. Jakarta:Pustaka Hidayah.

Muthahhari, Murtadha (1996) Masyarat dan Sejarah: Kritik Islam atas Marxisme dan Teori Lainnya. Bandung: Mizan.

Rahmena, Ali (ed.) (1995) Para Perintis Zaman Baru Islam, terjemahan. Bandung: Mizan.

Shalih, Subhi (1977) Mabahits fi 'Ulum al-Qur'an. Bairut: Dar al-'Ilm al-Malayin. Shihab, Quraish (1996) Membumikan al-Qur'an: Fungsi Wahyu dalam Kehidupan Masyarakat. Bandung: Mizan.

Syari'ati, Ali (1992) Humanisme antara Islam dan Mazhab Barat, terjemahan. Jakarta: Pustaka Hidayah.

al-Syathibiy, Abu Ishaq (t.th.) al-Muwafaqat di ('shul al-Syari 'ah. Juz III. Bairut: Dar al-Kutub al-llmiah.

Veeger, KJ. (1993) Realitas Sosial: Refleksi Filsafata Sosial atas Hubungan Individu-Masyarakat dalam Cakrawala Sejarah Sosiologi. Jakarta: PT. Gramedia Pustaka Utama.

Wafa, Muhammad (1984) Dilalat al-Awamir wa al-Nawahiy fi al-Kitab wa alSunnah. Mesir: Dar al-Iththiba'ah al-Muhammadiyah.

Wafi, Ali Abd al-Wahid (1962) 'Abd al-Rahman Ibn Khaldun. Kairo: Wazarah al-Tsaqafah.

Wignjosoebroto, Soetandyo (2003) “Dua Paradigma Klasik Untuk Memahami Dan/ Atau Menjelaskan Hakikat Ketertiban Dalam Kehidupan Bermasyarakat Manusia", Handout Filsafat Sosial 02.

(2003) "Pengantar: Apakah Filsafat Sosial Itu Dan Apa Pulakah MasalahMasalah Yang Diwacanakan?", Handout Filsafat Sosial 01.

al-Zarqani, Muhammad 'Abd al-Adhim (1988) Manahil al-'Irfan fi 'Ulum alQur'an, Vol. I. Bairut: Dar al-Fikr. 